\title{
Efektivitas Pelaksanaan Praktikum Anatomi Hewan Pendidikan Biologi FKIP UMS Tahun 2011/2012 dan 2012/2013 Ditinjau dari Nilai Akhir Praktikum
}

\author{
Endang Setyaningsih \\ Progam Studi Pendidikan Biologi, FKIP, Universitas Muhammadiyah Surakarta \\ Kampus I, Jl. Ahmad Yani Pabelan Kartasura, Tromol Pos I Surakarta 57I02 Indonesia \\ surat elektronik: es211@ums.ac.id
}

\begin{abstract}
ABSTRAK
Penerapan jadwal online menyebabkan pelaksanaan praktikum di prodi pendidikan biologi FKIP UMS tahun akademik (TA) 2012/2013 mengalami perubahan waktu. Hal ini mengakibatkan terjadinya perubahan sistem pelaksanaan praktikum mulai dari perencanaan, pengorganisasian, pelaksanaan, pengawasan, dan sistem evaluasi pembelajaran praktikum yang dapat mempengaruhi hasil belajar mahasiswa. Tujuan penelitian ini adalah untuk mengetahui efektivitas pelaksanaan praktikum Anatomi Hewan di laboratorium biologi tahun akademik 20II/20I2 dan 20I2/20I3 ditinjau dari nilai akhir praktikum. Jenis penelitian ini adalah Deskriptif kuantitatif dengan menggunakan uji rasio efektivitas untuk mengetahui seberapa besar tingkat persentase sasaran yang dicapai atas target yang telah ditetapkan dalam pelaksanaan praktikum Anatomi Hewan (AH) TA 20II/20I2 dan TA 2012/2013 dan Uji Mann-whitney (non parametrik) untuk mengetahui perbedaan efektivitas antara pelaksanaan praktikum AH TA 20II/20I2 dan 2012/2013 ditinjau dari nilai akhir praktikum. Sumber data dalam penelitian ini diperoleh melalui teknik dokumentasi dengan mengumpulkan data pada masing-masing tahun akademik. Hasil dari uji rasio efektivitas dapat diketahui bahwa rasio efektivitas TA $2011 / 2012$ adalah $88.08 \%$ dan rasio efektivitas TA 2012/2013 adalah 73.43\%. Suatu kegiatan dikatakan efektif jika mencapai rasio efektivitas diatas seratus persen. Hasil dari uji Mann-Whitney diketahui bahwa nilai probabilitas 0,000 < 0,05, maka Ho ditolak artinya ada perbedaan efektivitas yang signifikan antara pelaksanaan praktikum AH di laboratorium biologi UMS pada tahun akademik 20II/20I2 dan 2012/20I3 ditinjau dari nilail akhir praktikum. Dengan demikian dapat disimpulkan bahwa, pelaksanaan praktikum AH di laboratorium biologi FKIP UMS pada TA 20II/20I2 dan 2012/2013 sudah efektif namun ada perbedaan efektivitas yang signifikan antara pelaksanaan praktikum AH TA 20II/20I2 dan 2012/2013 ditinjau dari nilai akhir praktikum.
\end{abstract}

Kata kunci: Anatomi Hewan, efektivitas, dan rasio efektivitas

\section{Pendahuluan}

Salah satu bentuk dari keterampilan proses dalam pendidikan adalah kegiatan praktikum di laboratorium. Menurut Subiantoro (2009), berdasarkan terminologinya, praktikum dapat diartikan sebagai suatu rangkaian kegiatan yang memungkinkan seseorang menerapkan keterampilan atau mempraktikkan sesuatu. Dalam pembelajaran IPA, sesuatu ini merupakan prosesproses sains yang meliputi observasi, klasifikasi, mengukur, merekam, mengidentifikasi variabel, menginterpretasi data, memprediksi, inferensi, generalisasi, dan membuat keputusan. Dengan kata lain, di dalam kegiatan praktikum sangat dimungkinkan adanya penerapan beragam keterampilan proses sains sekaligus pengembangan sikap ilmiah yang mendukung proses perolehan pengetahuan (produk keilmuan) dalam diri seseorang. Di sinilah tampak bahwa praktikum memiliki kedudukan yang amat penting dalam pembelajaran IPA.

Dalam pengertian yang lebih khusus, praktikum merupakan salah satu bentuk kegiatan pembelajaran yang bertujuan untuk memantapkan pengetahuan mahasiswa terhadap materi perkuliahan melalui aplikasi, analisis, sintesis, dan evaluasi terhadap teori yang dilakukan baik di laboratorium ataupun di lapangan. Oleh karena itu pelaksanaan kegiatan praktikum di laboratorium harus dibuat dengan tujuan yang tepat agar praktikum dapat memperoleh hasil yang maksimal. Untuk menunjang kegiatan pembelajaran khususnya di 
laboratorium diperlukan pengelolaan pembelajaran yang efektif.

Pengelolaan pembelajaran merupakan hal yang sangat penting diperhatikan kaitannya dengan usaha perguruan tinggi untuk menghasilkan sumber daya yang berkualitas. Hal ini sangat penting karena denyut jantung sebuah perguruan tinggi untuk menghasilkan sumber daya yang berkualitas ditentukan oleh sejauh mana efektivitas pengelolaan pembelajaran tersebut dapat dikembangkan (Djamaluddin, 2005). Proses pembelajaran di perguruan tinggi dihadapkan kepada keadaan: I) cara penyajian, 2) hubungan dosen dengan mahasiswa, 3) hubungan antar mahasiswa, 4) bahan akademik, 5) fasilitas pembelajaran, 6) waktu pembelajaran.

Salah satu mata praktikum yang dilaksanakan di Laboratorium Biologi FKIP UMS adalah Anatomi Hewan (AH). Kegiatan praktikum AH wajib diikuti bagi mahasiswa semester III Program Studi Pendidikan Biologi. Kegiatan praktikum agar dapat berjalan dengan lancar, maka diperlukan pengelolaan yang tepat meliputi persiapan/perencanaan (planning), pengorganisasian (organizing), penggerakkan (actuating), pengawasan (controlling), dan sistem evaluasi (Sagala, 2006).

Berdasarkan penelitian Prastikawatik (2012), pelaksanaan praktikum SHV dengan menggunakan media video pembelajaran dan power point sudah memberikan pengaruh yang lebih baik terhadap hasil belajar mahasiswa. Hal ini menunjukkan bahwa pengelolaan sarana dan prasarana yang ada di Laboratorium Biologi UMS sudah digunakan secara optimal dan efektif. Berdasarkan penelitian Jumadi (2005), kriteria efektivitas adalah prestasi akademik yang digunakan dengan tes penguasaan konsep.

Selama ini, Program Studi Pendidikan Biologi Fakultas Keguruan dan Ilmu Pendidikan Universitas Muhammadiyah Surakarta sudah melaksanakan kegiatan praktikum. Pelaksanaan praktikum Biologi pada tahun akademik 20I I/20I2 ini mengalami perubahan berbeda dari tahun-tahun sebelumnya karena adanya penerapan peraturan baru pada jadwal online terpadu. Hal ini mengakibatkan terjadinya perubahan sistem pelaksanaan praktikum mulai dari segi waktu, pembagian jumlah asisten laboratorium dan mahasiswa, serta suasana belajar yang dapat mempengaruhi hasil belajar mahasiswa.

Kegiatan praktikum di Laboratorium Biologi terdiri dari kegiatan persiapan pembekalan praktikum dan kegiatan praktikum. Praktikum Anatomi Hewan, pada tahun akademik 20II/20I2 kegiatan praktikum AH dilaksanakan dengan jumlah mahasiswa atau praktikan sebanyak 40 orang setiap satu ruang, dan difasilitasi oleh 6 asisten laboratorium dan I dosen. Waktu kegiatan praktikum AH yaitu I50 menit (2,5 jam). Sedangkan tahun akademik 2012/2013, kegiatan praktikum AH dilaksanakan dengan jumlah mahasiswa atau praktikan sebanyak 20 orang setiap satu ruang, dan difasilitasi oleh
5 asisten laboratorium dan I dosen. Waktu kegiatan praktikum AH yaitu 100 menit (I jam 40 menit).

Berkurangnya waktu kegiatan persiapan pembekalan praktikum dan praktikum menjadi 100 menit, jumlah praktikan di dalam laboratorium menjadi 20 praktikan menyebabkan suasana pembelajaran lebih kondusif dan disiplin. Namun belum diketahui bagaimana hasil akhir belajar mahasiswa dengan adanya perubahan pelaksanaan praktikum, apakah ada perubahan kearah yang lebih baik atau tidak. Hal ini menyebabkan peneliti tertarik untuk melihat "Efektivitas Pelaksanaan Praktikum Anatomi Hewan Pendidikan Biologi FKIP UMS Ditinjau Dari Nilai Akhir Praktikum”.

Tujuan dari penelitian ini adalah untuk mengetahui efektivitas pelaksanaan praktikum Anatomi Hewan di laboratorium biologi tahun akademik 2011/2012 dan 2012/2013 ditinjau dari nilai akhir praktikum. Hasil dari penelitian ini diharapkan dapat menjadi bahan evaluasi dalam pelaksanaan praktikum di laboratorium dan bermanfaat untuk meningkatkan proses kegiatan belajar mengajar khususnya di Laboratorium Biologi UMS.

\section{Metode Penelitian}

Penelitian ini dilakukan di Laboratorium Biologi FKIP UMS, pada bulan Juli 2013 - Januari 20I4. Jenis penelitian ini adalah penelitian deskriptif kuantitatif yang bertujuan untuk mengetahui efektivitas pelaksanaan praktikum anatomi hewan pada tahun ajaran 2011/2012 dan tahun ajaran 2012/2013 berdasarkan nilai akhir praktikum.

Populasi pada penelitian ini adalah seluruh mahasiswa biologi yang mengikuti mata praktikum Anatomi hewan pada tahun ajaran 201I/2012 dan 2012/2013. Sampel yang digunakan dalam penelitian ini sama dengan populasi yang digunakan pada penelitian ini. Jadi, sampel pada penelitian ini adalah seluruh mahasiswa biologi yang mengikuti praktikum anatomi hewan pada tahun ajaran 201I/20I2 (I55 mahasiswa) dan tahun ajaran 2012/2013 (I55 mahasiswa).

Variabel yang digunakan pada penelitian ini terdiri dari dua variabel, yaitu variabel bebas dan variabel terikat. Variabel bebas yaitu Praktikum anatomi hewan tahun ajaran 20II/2012 dan tahun ajaran 2012/2013. Variabel terikat yaitu nilai praktikum anatomi hewan pada tahun ajaran 2011/2012 dan 2012/2013.

Teknik pengumpulan data menggunakan teknik dokumentasi. Peneliti mengumpulkan data berupa data pelaksanaan praktikum dan data nilai praktikum anatomi hewan tahun ajaran 2011/2012 dan 2012/2013 yang terdiri dari skor. Data pelaksanaan praktikum meliputi kegiatan perencanaan, pelaksanaan, dan evaluasi. Data nilai praktikum terdiri dari skor Pretest, skor laporan, skor keaktifan, dan skor ujian akhir praktikum. 
Analisis data yang digunakan adalah rasio efektivitas. Rasio efektivitas digunakan untuk mengetahui seberapa besar tingkat presentase yang dicapai atas target yang telah ditentukan pada pelaksanaan praktikum anatomi hewan TA 2011/2012 dan 2012/2013. Untuk mengkaji apakah terdapat perbedaan efektivitas yang signifikan antara pelaksanaan praktikum anatomi hewan TA 201I/2012 dan 2012/20I3. Digunakan uji hipotesis menggunakan uji Independent sample t-test. Dengan syarat data berdistribusi normal dan memiliki varian data yang homogen. Jika tidak memenuhi persyaratan tersebut maka digunakan statistik non parametrik yaitu uji Mann-whitney.

\section{Hasil dan Pembahasan}

Hasil rekapitulasi data nilai praktikum anatomi TA 20II/20I2 dan TA 2012/2013 dapat dilihat dari tabel I berikut.

Tabel I. Rekapitulasi data nilai praktikum anatomi hewan TA 20II/20I2 dan TA 20I2/20I3.

\begin{tabular}{|c|c|c|c|c|c|c|c|c|}
\hline \multirow{2}{*}{ Nilai } & \multicolumn{4}{|c|}{ TA $2011 / 2012$} & \multicolumn{4}{|c|}{ TA 20I2/20I3 } \\
\hline & Pre-test & Laporan & Keaktifan & Ujian akhir & Pre-test & Laporan & Keaktifan & Ujian akhir \\
\hline Rata-rata & 50.56 & 87.55 & 79.51 & 71.39 & 51.62 & 80.78 & 73.26 & 67.7 \\
\hline Tertinggi & 73.4 & 96.78 & 81.6 & 86 & 79.50 & 93.38 & $8 \mathrm{I}$ & 92.30 \\
\hline Terendah & 22.8 & 69.8 & $7 \mathrm{I} .6$ & 54 & 19.17 & 65.79 & 65 & 20.60 \\
\hline Modus & $4 \mathrm{I} .5$ & 80.5 & 79.2 & 73.85 & 46.90 & 86.10 & 75 & 69.00 \\
\hline Median & 47.5 & 89.78 & 77.4 & 74.2 & 50.24 & 80.92 & 74 & 70.15 \\
\hline Kognitif & \multicolumn{4}{|c|}{69.03} & \multicolumn{4}{|c|}{65.2} \\
\hline Afektif & \multicolumn{4}{|c|}{$78.5 \mathrm{I}$} & \multicolumn{4}{|c|}{74.26} \\
\hline Psikomotor & \multicolumn{4}{|c|}{72.39} & \multicolumn{4}{|c|}{66.7} \\
\hline
\end{tabular}

Hasil penelitian rasio efektivitas pelaksanaan praktikum anatomi hewan TA 2011/2012 dan TA 2012/2013 ditinjau dari nilai praktikum disajikan dalam tabel 1 .

Tabel 2. Rekapitulasi rasio efektivitas praktikum anatomi hewan TA 2011/2012 dan TA 2012/2013 berdasarkan nilai akhir praktikum

\begin{tabular}{cccc}
\hline $\begin{array}{c}\text { Tahun } \\
\text { akademik }\end{array}$ & $\begin{array}{c}\text { Target } \\
\text { efektif }\end{array}$ & $\begin{array}{c}\text { Rasio efektivitas } \\
(\%)\end{array}$ & Kriteria \\
\hline $2011 / 2012$ & $\geq$ Nilai B & 88.08 & Efektif \\
$2012 / 2013$ & $\geq$ Nilai B & 73.43 & Efektif \\
\hline
\end{tabular}

Berdasarkan tabel I Pelaksanaan praktikum anatomi hewan pada TA 20I I/2012 dan TA 2012/2013 dinilai efektif. Penilaian tingkat efektivitas berdasarkan uji rasio efektivitas, yaitu perbandingan antara realisasi jumlah mahasiswa yang memperoleh nilai $\geq$ nilai $\mathrm{B}$, dengan realisasi jumlah mahasiswa yang memperoleh nilai $<$ B. Jika jumlah mahasiswa yang memperoleh nilai $\geq$ B lebih

Tabel 3. Hasil analisis uji normalitas pelaksanaan praktikum anatomi hewan pada tahun ajaran 2012/2013 dan tahun ajaran 2013/20I4.

\begin{tabular}{|c|c|c|c|c|c|c|c|}
\hline & \multirow[t]{2}{*}{ Tahun Ajaran } & \multicolumn{3}{|c|}{ Kolmogorov-Smirnov(a) } & \multicolumn{3}{|c|}{ Shapiro-Wilk } \\
\hline & & Statistic & df & Sig. & Statistic & df & Sig. \\
\hline \multirow[t]{2}{*}{ nilai } & $2011 / 2012$ & .075 & $\mathrm{I} 55$ & .035 & .978 & I55 & .015 \\
\hline & $2012 / 2013$ & .066 & I4I & $\left..200{ }^{* *}\right)$ & .982 & I4I & .068 \\
\hline
\end{tabular}

* Ini adalah batas bawah dari signifikansi sebenarnya

a koreksi signifikansi Lilliefors

Berdasarkan tabel 2 menunjukkan bahwa, nilai probabilitas (Sig.) dengan tabel Kolmogorov-Smirnov pada TA $2011 / 2012$ ialah $0.035<0.05$. hal ini menunjukkan bahwa data berdistribusi tidak normal. banyak dibanding jumlah mahasiswa yang memperoleh nilai $<$ B, maka pelaksanaan praktikum anatomi hewan berdasarkan nilai praktikum dapat dikatakan efektif.

Untuk mengkaji apakah terdapat perbedaan efektivitas yang signifikan antara pelaksanaan praktikum anatomi hewan TA 201I/2012 dan 2012/2013 ditinjau dari nilai praktikum maka digunakan uji hipotesis menggunakan uji independent sample $t$ test dengan syarat data berdistribusi normal dan memiliki varian data yang homogen. Untuk mengetahui apakah data berdistribusi normal maka digunakan uji normalitas, sedangkan untuk mengetahui apakah data memiliki varian data yang homogen maka digunakan uji homogenitas. Jika data tidak memenuhi persyaratan tersebut maka analisis statistik yang digunakan adalah analisis statistik non parametrik Mann-whitney.
Sedangkan pada TA 2012/2013 nilai probabilitas yang dihasilkan ialah 0.2. Hal ini menunjukkan bahwa data berditrinusi normal. Hasil keseluruhan dari uji normalitas yaitu data tidak berdistribusi normal. 
Tabel 3. Hasil analisis uji homogenitas pelaksanaan praktikum anatomi hewan pada tahun ajaran 201 I/2012 dan tahun ajaran 2012/2013.

\begin{tabular}{|ll|r|r|r|r|}
\hline & \multicolumn{1}{c|}{$\begin{array}{c}\text { Statistic } \\
\text { Levene }\end{array}$} & dfI & \multicolumn{1}{c|}{ df2 } & \multicolumn{1}{c|}{ Sig. } \\
\hline Nilai & Based on Mean & $4.23 \mathrm{I}$ & $\mathrm{I}$ & 294 & $.04 \mathrm{I}$ \\
& 3.972 & $\mathrm{I}$ & 294 & .047 \\
& Based on Median & & & \\
& Based on Median and with & 3.972 & $\mathrm{I}$ & 284.445 & .047 \\
& adjusted df & & & \\
& Based on trimmed mean & 4.228 & $\mathrm{I}$ & 294 & $.04 \mathrm{I}$ \\
\hline
\end{tabular}

Berdasarkan tabel 3 menunjukkan bahwa, nilai probabilitas (Sig.) based on mean ialah 0.04I $<0.05$. Hal ini menunjukkan bahwa data tidak mempunyai varian yang sama (tidak homogen). Berdasarkan uji prasyarat normalitas dan homogenitas, dapat disimpulkan bahwa data yang digunakan tidak berdistribusi normal dan tidak memiliki varian yang sama. Maka untuk uji hipotesis menggunakan uji nonparametrik Mann-Whitney.

Tabel 4. Hasil analisis uji statistic Mann-Whitney U pelaksanaan praktikum anatomi hewan pada tahun ajaran 20II/20I2 dan tahun ajaran $2012 / 2013$.

\begin{tabular}{|l|r|}
\hline & nilai \\
\hline Mann-Whitney U & 7066.000 \\
\hline Wilcoxon W & $\mathrm{I} 7077.000$ \\
\hline Z & -5.250 \\
\hline Asymp. Sig. (2-tailed) & .000 \\
\hline
\end{tabular}

a Pengelompokan Variabel: Tahun ajaran

Berdasarkan tabel 4 menunjukkan bahwa perbandingan efektivitas antara praktikum anatomi hewan TA 20II/20I2 dan TA 2012/2013 memiliki nilai probabilitas yaitu $0.000<0.05$, maka HO ditolak artinya ada perbedaan efektivitas pelaksanaan praktikum anatomi hewan di laboratorium biologi ditinjau dari nilai praktikum. Dengan demikian hasil dari penelitian ini menunjukkan bahwa pelaksanaan praktikum anatomi hewan TA 201I/20I2 dan TA 2012/2013 dinilai efektif, dan yang paling efektif adalah TA 201 I/20I2.

Perbedaan efektivitas ini dapat dilihat melalui beberapa faktor, yaitu input, Proses, dan output dari praktikum anatomi hewan. Input dari praktikum anatomi hewan merupakan peserta didik. Kualitas peserta didik praktikum anatomi hewan TA 20II/20I2 dan TA 2012/2013 berbeda. Mahasiswa yang mengikuti praktikum anatomi hewan TA 20II/20I2 memiliki kualitas yang lebih tinggi dibanding mahasiswa yang mengikuti praktikum anatomi hewan TA 2012/2013. Hal ini dapat dilihat dari tabel I, praktikan anatomi hewan TA 20II/2012 memiliki rata-rata skor kognitif yang lebih tinggi dibanding praktikan anatomi hewan TA 20I2/2013.

Proses pelaksanaan praktikum terdiri dari dua kegiatan, yaitu kegiatan pembekalan dan kegiatan praktikum. Pada kegiatan pembekalan dan praktikum anatomi hewan TA 2011/2012 terdapat beberapa gelombang dengan alokasi waktu I50 menit. Setiap kelas terdapat 40 praktikan yang didampingi oleh I dosen dan 8 asisten. Sedangkan pelaksanaan praktikum anatomi hewan TA 2012/2013 alokasi waktunya 100 menit, setiap kelas terdapat 20 praktikan yang didampingi I dosen dan 5 asisten. Pada pelaksanaan praktikum anatomi hewan TA 20II/20I2 praktikan setelah melakukan sectio, hasil sectio langsung digambar dan diberi keterangan organ-organnya, namun pada pelaksanaan praktikum TA 20I2/2013, sebelum melakukan sectio setiap kelompok dibekali dengan LKM untuk membantu dalam memahami materi anatomi hewan, kemudian setelah sectio, preparat langsung difoto dan menggambarnya dirumah berdasarkan foto yang didapat saat praktikum.

Berdasarkan analisis data menujukkan bahwa kelas kecil dan adanya LKM tidak begitu berpengaruh secara signifikan dalam pembelajaran tapi justru ketrampilan psikomotor saat pembedahan yang langsung disambung dengan menggambar serta menganalisa hasil praktikum saat itu juga, itu yang mempengaruhi perbedaan nilai akhir praktikum. Hal ini sesuai dengan apa yang dikatakan Rahmat (2010), menurutnya, efektivitas pembelajaran di kelas tidak hanya dipengaruhi jumlah siswa dalam kelas, melainkan lebih banyak dipengaruhi oleh efektivitas guru mengajar dan aplikasi pembelajaran dikelas. Dosen praktikum sama akan tetapi asisten praktikum anatomi hewan setiap tahunnya berbeda, sehingga hasil yang diperoleh juga berbeda. Hal ini didukung oleh Mauhazizin (2012) yang menyatakan bahwa kompetensi guru dan ketrampilan psikomotorik berpengaruh positif terhadap hasil belajar siswa, karena ketika kompetensi guru meningkat maka hasil belajar siswapun akan meningkat dan ketika ketrampilan psikomotor meningkat maka hasil belajar siswa juga ikut meningkat. 
Output dari praktikum anatomi hewan merupakan hasil belajar peserta didik. Menurut Yulia (2012) hasil belajar adalah kemampuan yang dimiliki siswa setelah menerima pengalaman belajar. Kemampuankemampuan tersebut mencakup aspek kognitif, afektif, dan psikomotorik. Berdasarkan uraian yang telah disampaikan diatas, hasil belajar pada praktikum anatomi hewan sudah termasuk baik, karena memliki aspek kognitif, afektif, dan psikomotorik. Namun hasil yang diperoleh yaitu pelaksanaan praktikum anatomi hewan mengalami penurunan dan belum sesuai dengan tujuan yang diharapkan. Input dan proses praktikum anatomi hewan yang berbeda antara TA 20II/20I2 dan TA 2012/2013 mempengaruhi nilai akhir yang didapatkan, karena Pengelolaan sistem pembelajaran praktikum anatomi hewan TA 2012/2013 ternyata membawa ke hasil yang lebih tinggi. Hal ini didukung oleh Widyarani (20II) yang meyatakan bahwa, pengelolaan kelas berpengaruh positif terhadap pembelajaran efektif.

\section{Simpulan}

Berdasarkan penelitian yang telah dilakukan maka dapat disimpulkan bahwa Pelaksanaan praktikum anatomi hewan di laboratorium Biologi UMS ditinjau dari nilai akhir praktikum adalah efektif (TA 201I/2012 dan 2012/2013) dan yang paling efektif adalah pada TA 2012/2013.

\section{Saran}

Saran dari penelitian yang telah dilakukan adalah perbaikan standar penilaian mata kuliah untuk pembelajaran yang lebih baik dan peningkatan pengelolaan pembelajaran dalam pelaksanaan praktikum dengan memunculkan inovasi-inovasi sehingga dapat membantu praktikan dalam proses belajar yang lebih efektif lagi.

\section{Daftar Pustaka}

Djamarah, S \& Zain, A. 20I0. Strategi Belajar Mengajar: Jakarta: Rineka Cipta.

Handoko, Hani. 2003. Manajemen, Edisi Kedua. Yogyakarta: BPFE.

Mauhazizin, Aa Syamsul. 2012. Pengaruh Kompetensi Guru Dan Motivasi Belajar Siswa Terhadap Hasil Belajar Pada Mata Pelajaran Ips : Survey Pada Siswa Smp Di Kabupaten Purwakarta. Thesis. Bandung: Universitas Pendidikan Indonesia.

Rahmat. 20I0. Mitos Jumlah Siswa Per Rombongan Belajar, Makin Sedikit Makin Baik. Tersedia di: http://gurupembaharu.com/home/mitos-jumlah-siswaper-rombongan-belajar-makin-sedikit-makin-baik/. Diakses 09;00 AM, 21/07/2014.

RMP - Biologi FKIP UMS. 20I4. Praktikum Anatomi Hewan. Tersedia di

http://rmp.ums.ac.id/courses/detail/A420/307202P. Diakses 08;00 AM, I0/0I/20I4.

Subagyo, Ahmad Wito. 2000. Efektivitas Program Penanggulangan Kemiskinan dalam Pemberdayaan Masyarakat Pedesaan. Yogyakarta: UGM.
Widyarani, Diana. 20I I. Pengaruh Kompetensi Guru Dan Motivasi Belajar Siswa Terhadap Hasil Belajar Pada Mata Pelajaran Ips: Survey Pada Siswa Smp Di Kabupaten Purwakarta. Skripsi. Jakarta: UIN Syarif Hidayatullah.

Yulia, S. 2012. Pengertian Hasil Belajar. Tersedia: http://eprints.uny.ac.id/9829/2/bab2.pdf. Diakses 08;00 AM, 20/0I/20I4. 